\title{
Minjiang River Mainstream Water Ecological Protection and Restoration
}

\author{
Liang Qiu ${ }^{1, a}$, Xiaoyong Luo ${ }^{1, b}$ \\ ${ }^{1}$ Changjiang Water Resources Protection Institute, Wuhan, Hubei, 430051,China \\ a sharptiger@126.com, blxy2208@tom.com
}

\begin{abstract}
Key words: Minjiang Rive Mainstream, Flood, Ecological Protection, Ecological Restoration
Abstract. The Minjiang river basin resources are very rich, but the water and other natural disasters happen often; Infrastructure construction is weak, and the ability to resist disasters is low, economic development relative lag; Ecological environment destruction by artificial and natural factors, in order to protect and repair the river ecological environment of Minjiang river, a serious methods should be taken, including strengthen the overall planning, strengthen management.
\end{abstract}

\section{Introduction}

Minjiang river is an important anabranch of the Yangtze river upstream, and it is located in the abdominal area in the western of Sichuan province basin edge, originated in Sichuan and Gansu provinces border minshan south; Minjiang river have east and west two source, it flow from north to south through the Maoxian, Wenchuan and Dujiangyan Railway Station, it divided into two rivers by the Dujiangyan Railway Station, flow through Chengdu plain, then join in Pengshan, then feeds into Yangtze river. Minjiang river total length is $735 \mathrm{~km}$, the basin area is $135881 \mathrm{~km}^{2}$, average slope of $4.84 \%$.

According to the characters of natural geography and river, Minjiang river above the Dujiangyan Railway Station called upstream, from the Dujiangyan Railway Station to Leshan called midstream, Leshan downstream called downstream. Minjiang river's main tributaries have Dadu river and Qingyi river, Black river, Zagunao river, Yuzi valley, Mabian river and Longxi river, etc.

\section{The state of Minjiang river basin}

The Minjiang river basin has rich hydropower resources, forest resources, mineral resources and a large number of rare wild animals and plants. Chengdu section is main flood-relief river course of Minjiang river flow into the plain river; several floods happen in history, at present, the river regulation project of Minjiang river basin is given priority to with embankments, reservoir as the auxiliary pole. Since 1991, prefecture and geological environmental monitoring station was established in the valley of Minjiang river in sichuan province, promote the Minjiang river valley geological disaster prevention and geological disaster monitoring work. Minjiang river basin is located in the southwest, infrastructure is weak, low ability to resist disasters, and economic development is relatively lagging behind. In the ' $60 \mathrm{~s}$, due to excessive cutting wood, logging and destroying forest, river water and soil resources were serious damage. After entering the $70 \mathrm{~s}$, water conservation project has been developed gradually, mainly measures such as tree planting and afforestation were adopted. In recent years, some measures of the comprehensive harness of soil and water conservation are carried out in Minjiang river basin, successively carried out such as natural forest protection project, returning farmland to forest, and ecological environment is 
improved significantly before governance.

\section{The main ecological environment problems}

Though the work of governance, development and protection of Minjiang river valley achieve significant achievements, still has certain gap with the strategic demands of comprehensive construction well-off society, building a harmonious society, building a resource-conserving and environmentally friendly society.

The gap mainly reflects in five aspects:

First, Minjiang river a lack of comprehensive planning, and a lack of management, development and utilization from the macro guidance of the whole river basin. In history Minjiang river had sectorial flood control planning, hydropower development planning and other planning, but there is no complete basin comprehensive planning to guide river management, development, protection and unified management. Minjiang river basin comprehensive planning lags behind the relevant professional planning, affect the development of river basin water resources comprehensive benefits.

Second, the flood control works and flood control system is not sound. For many years the Minjiang river valley was predominantly levee revetment flood control project construction has made big achievements, but there are still many problems: the whole river flood control system is not for full system planning; Most of the flood control engineering is local levee revetment engineering, most cities did not form a complete circle, the overall flood control ability is bad, will not fundamentally eliminate the flood disaster; Existing part of the old embankment construction, engineering quality is poor, do not meet the design standards; Existing flood warning system is imperfect, and incomplete, communications equipment lag behind, personnel absence, command scheduling is not standard; In recent years Minjiang river for continuous dry year, with the running of some reservoirs, river water reduce in most of the time, easy to form man-made disasters when project scheduling improper or occasional floods, attention should be attached to it of the governments at all levels.

Third, the water resources reasonable development and utilization still need to strengthen. Minjiang river basin water project construction is insufficient, and low regulation ability of water resources, rivers cannot give full play to the service function. Minjiang river water resources are abundant, but uneven distribution of time and space, lead to local region water resources are tight. At the same time, the construction of water-saving society in the basin has not been due attention, the Minjiang river valley water saving irrigation area of less than $30 \%$ of effective irrigation area, the industrial repeated water utilization ratio is less than $50 \%$.

Basin hydropower resources development are not balance, progress is uneven, fewer large controlling engineering. Upstream of Minjiang river valley was rich in hydropower resources, the development and utilization of the hydropower resources in a long time ago, but large and medium-sized less control engineering construction is less. The hydropower resources development of midstream and downstream may face problem of ecological environment protection and the submerged immigrants, so the progress has been slow. Minjiang river channel functioning was limited; port infrastructure is weak, restricting the development of water transportation advantage. At the same time, the Minjiang river waterway withered level days change is bigger, seriously affect the safe navigation of the ship.

Forth, the ecological environment protection needs increasing. As basin population increase, urban scale, industrial and living sewage wastewater emissions increase, the local river and part of 
the main river tributary water pollution is serious. 24 water function area in Minjiang river, there is 16 water quality standard in the whole year, the standard rate is $66.7 \%$.

There is $7900 \mathrm{~km}^{2}$ area of soil and water loss in Minjiang river basin need to be controlled. Development and construction project caused the problems soil and water loss more serious. At the same time, combined with the "5.12" Wenchuan earthquake, lots of vegetation damage, soil exposed, crushing of rock mass, and a heavy rain booster effect, easy to create the geological disasters such as landslide and debris flow.

Five, measures of management backward and water resources scheduling are not adapt to the requirement of economic and social development. So as to maintain Minjiang river health, promote people and water in harmony, to ensure the safety of the river basin flood control, water supply security, food security and ecological security, watershed management needs to be further strengthened.

It is necessary to strengthen the integration management; efficient cross-sector cross-industry coordination mechanism is not been established. In the basin water resources market allocation mechanism, and public participation mechanism also need to actively cultivate and perfect. Basin existing laws and regulations system about water is only in its infancy, it need further perfect. River basin water administration affairs management has to be further standardized and institutionalized; Information modernization level and the supporting ability of science and technology need further improved.

\section{Protection and restoration measures}

Establish long-term effective whole plan, is an inevitable requirement to insure the effect of ecological protection and restoration measures, is a practical guarantee for the harmonious development of man and nature and to establish environmental friendly society. The establishment of whole plan needs not only the social perfect laws and regulations as the foundation of implementation, also needs national policy to guidance and promote.

In order to solve the above problems, first of all, make a whole plan have of Minjiang river mainstream; formulate guiding ideology and principle, definite management goals and tasks of the plan.

Second, Minjiang river basin water resources is abundant, but the utilization rate is low, uneven space-time distribution of water resources, per capita, per acre is not high, Water infrastructure construction lag behind, lack of storage capacity evaluate the utilization of water resources, and make comprehensive utilization of water resources planning, including irrigation, shipping, water power, etc.

Third, the Minjiang river basin flood is frequently, for protecting the safety of the people's life and property along the river, flood control planning should be made, including flood control planning principle, standard, goal, the city flood control plan, mountain torrent disaster prevention and control planning.

Minjiang river basin flood control system include: flood control reservoir and downstream of the embankments and revetment engineering construction, construction of flood control and command system and decision support system construction.

Fourth, make water conservation planning, including clear water function zoning, water resources protection planning goal and layout, the water pollution status quo and protection measures, etc.

At present, the Minjiang river basin water pollution is increasingly serious; including water 
resource overexploitation, part of the river flow, upstream water loss and soil erosion is aggravating, eutrophication. So, it is need to increase the intensity of pollution sources control, ensure the river ecological water requirement, increasing water comprehensive management, and increase the source of drinking water protection measures.

Fifth, make water ecological and environmental protection and restoration planning, including investigation existing problems and the present situation of the ecological environment water, clear object and scope of the ecological and environmental protection, water ecology and environmental protection planning goal and the layout, repair planning advice.

Disordered development of water resources lead river water ecological environment deterioration, and gradually reduce the number of biological species, wetland area. At the same time, ecological environment protection investment and management is not enough, natural reserve distribution uneven.

Sixth, make soil and water conservation planning, including status quo and existing problems of soil and water loss, comprehensive prevention and control planning, monitoring of soil and water conservation planning, research and demonstration promotion planning. We must stick to the policy of "prevention first, protection priority", comprehensive legal, administrative, and vegetation restoration measures to protect vegetation.

\section{Conclusions}

With the development of resources, Minjiang river basin water resources reduced, increasing water pollution, a sharp drop in forest area and biodiversity damaged. To protect the Minjiang river mainstream ecology and environment, and promote the harmonious development of people and water, a series of rational plans must be taken. To strengthen the Minjiang river mainstream water resources protection, promote the structural of aquatic biodiversity integrity, should strengthen the Minjiang river mainstream water resources allocation and management, and speed up the economic structural adjustment and optimization of industrial layout. Strengthening water ecological protection and restoration, meanwhile strengthen the Minjiang river mainstream water pollution prevention and control and conduct ecological compensation mechanism research and pilot.

\section{References}

[1] W Wettstein, B Schmid. Conservation of Arthropod Diversity in Montane Wetlands: Effect of Altitude, Habitat Quality and Habitat Fragmentation on Butterflies and Grasshoppers. Journal of Applied Ecology- 1999

[2] N Gordon-Bradley, DS Lymperopoulou, HN Williams. Differences in Bacterial Community Structure on Hydrilla verticillata and Vallisneria americana in a Freshwater Spring. Microbes \& Environments - 2014 